\title{
THE CENSUS OF SMS GATEWAY BASED WEB BASED KOTO LUAR PAUH DISTRICTS PADANG CITY
}

\author{
Danyl Mallisza \\ Danylmallisza2483@gmail.com \\ D III Manajemen Informatika Dan Komputer \\ Universitas Ekasakti
}

\begin{abstract}
SMS) plays an important role in the field of IT in the future, SMS GATEWAY can be used as a mobile device for collecting data in the population census in achieving the availability and effectiveness. This research is about the development of software based on short message service (SMS) system to send messages via SMS gateway. The main objective of the proposed system is to provide a multi-level local authentication services to the SMS gateway. This service can be implemented in multi-departmental organizations where SMS service is used for system notifications. The proposed system has a web interface and encryption methods to provide services. Census information system that uses a computerized system is an effort to help smooth in the world of government so that the data obtained more precise and accurate. It can be expected to facilitate the penyensusan population in Koto village of Padang Pauh Subdistrict Affairs effectively, efficiently and accurately to improve government performance.
\end{abstract}

Keywords: IT, SMS Gateway, Census, government.

\section{PENDAHULUAN}

Pada Saat ini untuk sistem sensus penduduk pada Kelurahan Koto Luar Kecamatan Pauh Kota Padang masih menggunakan cara manual sehingga sering terjadi kesalahan pada waktu pendataan dan memperlambat proses kerja petugas.sistem sensus penduduk yang sedang berjalan saat ini sangatkurang efektif dan efisien karena masih banyak timbul berbagai masalah dalam prosesnya dikarenakan system sensus yang ada saat ini dilakukan secara manual pada Kelurahan Koto Luar Kecamatan Pauh Kota Padang. Untuk itu langkah awal yang akan di lakukan oleh Kelurahan Koto Luar Kecamatan Pauh Kota Padang adalah memperbaiki system sensus terutama pada sistem sensus penduduk yang sedang berjalan saat ini. Seiring perkembangan dalam dunia pemerintahan yang semakin besar, maka semakin banyaknya informasi yang dibutuhkan dalam desa tersebut. Sistem informasi sensus yang menggunakan sistem komputerisasi merupakan salah satu upaya untuk membantu kelancaran di dunia pemerintahan sehingga data yang didapat lebih tepat dan akurat. Hal tersebut dapat diharapkan akan memudahkan dalam penyensusan penduduk pada Kelurahan Koto Luar Kecamatan Pauh Kota Padang secara efektif, efisien dan akurat untuk meningkatkan kinerja pemerintah. 


\section{SMS Gateway}

SMS Gateway adalah suatu aplikasi SMS yang dapat disimulasikan sebagai sebuah gerbang yang menghubungkan antara komputer dengan client melalui pesan sms yang dikirim ataupun diterima menggunakan gateway device, terintegrasi dengan database server, yang secara otomatis dapat mendistribusikan pesan SMS. SMS gateway merupakan sebuah sistem aplikasi yang digunakan untuk mengirim dan atau menerima SMS, dan biasanya digunakan pada aplikasi bisnis, baik untuk kepentingan broadcast promosi, servis informasi terhadap pengguna, penyebaran content produk / jasa dan lain lain. Beberapa fitur yang umum dikembangkan dalam aplikasi SMS Gateway:
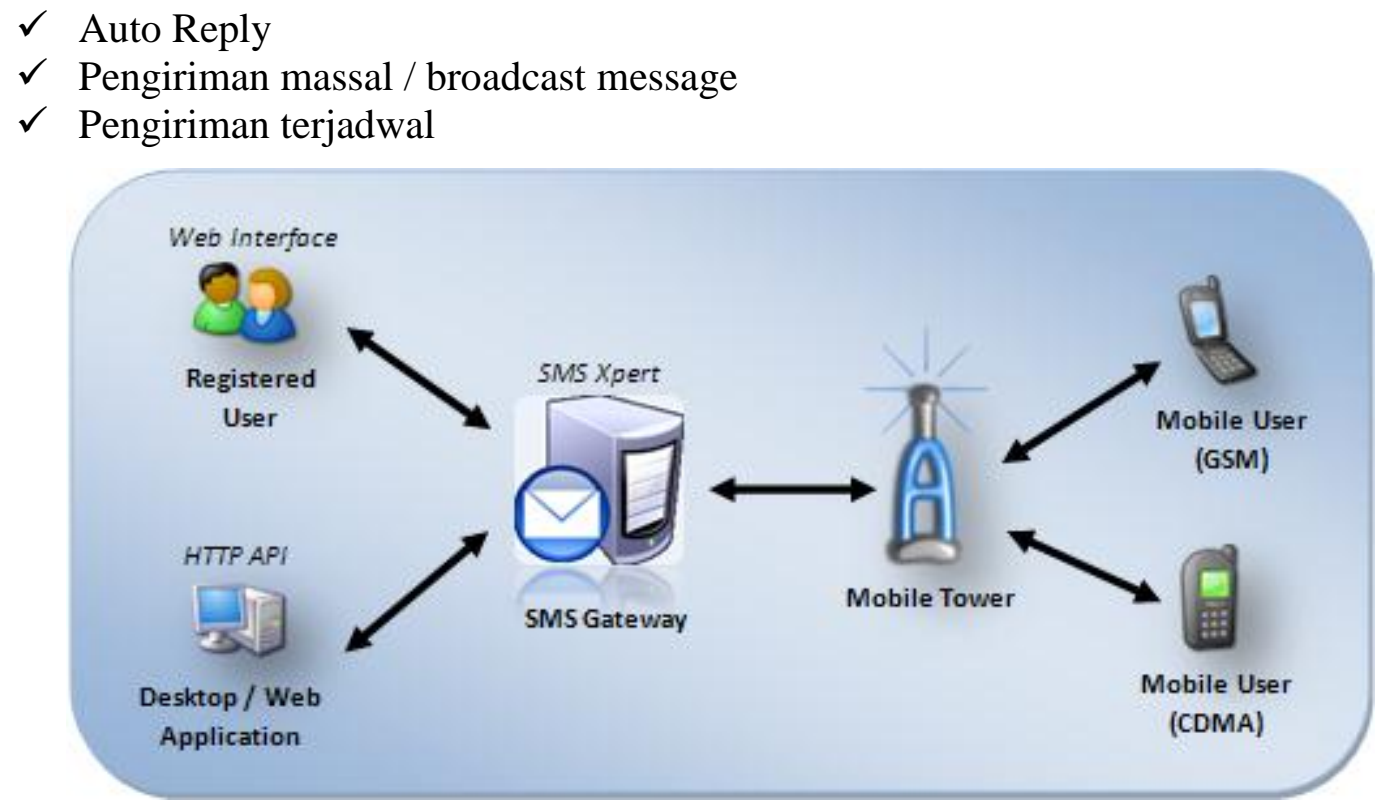

\section{Skema SMS Gateway}

Saat membuat SMS Gateway, kita membutuhkan SMSC (Short Message Service Center). yang merupakan jaringan telepon selular yang menangani pengiriman SMS. Jadi SMSC-lah yang bertugas mengirimkan pesan tersebut ke nomer tujuan. Jika nomer tujuan tidak aktif, maka SMSC akan menyimpan pesan tersebut dalam jangka waktu tertentu, Jika SMS tetap tidak dapat terkirim sampai jangka waktu tersebut berakhir, maka SMS tersebut akan dihapus dari penyimpanan SMSC.

\section{Gammu}

Untuk menunjang pembuatan Sms Gateway di perlukan tools pendukung, yaitu Gammu. Gammu adalah suatu aplikasi cross-platform yang berfungsi untuk menjembatani antara database SMS Gateway dengan sms device. Gammu merupakan suatu daemon yang berjalan secara background. Gammu selalu memonitor sms device dan database sms gateway, saat ada sms yang masuk Gammu langsung menempatkannya ke inbox database sms gateway dan saat aplikasi pengirim sms memasukkan sms ke dalam outbox dalam database sms gateway, maka gammu mengirimkan melalui sms device dan 
memindahkannya ke sent item database. Kemampuan gammu selain bisa untuk mengirim/menerima SMS, Gammu juga dapat mengirim/menerima MMS, backup/restore phonebook, serta upload/download file ke MobileEquipment. Selain itu Gammu juga support untuk lebih dari 400 jenis MobileEquipment. Kelebihan Gammu dari tool SMS gateway lainnya adalah:

$\checkmark$ Gammu dapat dijalankan di Windows maupun Linux .

$\checkmark$ Banyak device atau ponsel yang kompatibel dengan gammu.

$\checkmark$ Gammu dapat menggunakan database MySQL.

$\checkmark$ Gammu dapat membantu menggunakan fitur-fitur yang ada pada ponsel dengan lebih efisien .

$\checkmark$ Baik kabel data USB maupun SERIAL semuanya kompatibel di Gammu.

\section{METODE PENELITIAN}

Konsep metodologi penelitian yang dilakukan adalah melakukan pendekatan solusi berbasis tujuan (Studi literatur), identifikasi masalah penentuan fokus dari penelitian, perancangan dan pengembangan solusi, pembuatan simulasi, pengujian, pembahasan, pengambilan kesimpulan. Pendekatan ini menggunakan konsep yang diperkenalkan oleh Ken Peffers, Tuure Tuunanen, Marcus A. Rothenberger, dan Samir Chatterjee pada jurnal berjudul "A Design Science Research Methodology for Information Systems Research" . Bagan alir dapat dilihat pada Gambar dibawah ini.

Berdasarkan konsep tersebut, metode penelitian yang disesuaikan dengan penelitian yang dilakukan memiliki tahapan studi literatur, identifikasi masalah dan motivasi, penentuan fokus (tujuan) dari penelitian, perancangan dan pembuatan prototipe aplikasi,Demonstrasi aplikasi, Pengujian aplikasi, Analisis, dan Pelaporan hasil penelitian. Penjabaran metode yang digunakan berdasarkan tahapan penelitian adalah sebagai berikut:

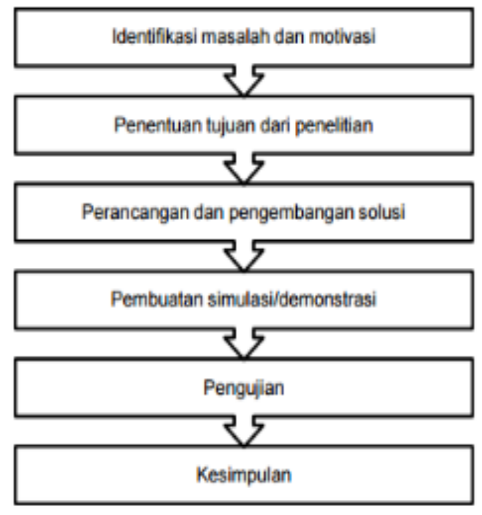

Gambar Framework

1. Studi Literatur Studi dilakukan terhadap jurnal penelitian internasional, tesis dan disertasi nasional dan internasional, dan buku-buku teori pendukung nasional dan internasional. Peneliti melakukan analisis, interpretasi, dan generalisasi faktafakta 
dari literatur yang didapatkan. Studi juga dilakukan terhadap kondisi saat ini melalui pengumpulan data-data yang tersedia.

2. Identifikasi Masalah dan Motivasi Dilakukan identifikasi masalah yang ada, terutama berdasarkan teknologi dan kondisi yang ada. Dilakukan kajian untuk memahami dan menentukan motivasi berdasarkan hasil dari studi literatur.

3. Fokus penelitian adalah perancangan dan pembuatan aplikasi Pembuatan proposal dilakukan sebagai pedoman dalam melakukan penelitian.

4. Perancangan dan Pembuatan Aplikasi Perancangan dan pembuatan solusi berdasarkan fokus dari penelitian dikerjakan dengan metode pengembangan perangkat lunak dalam melakukan desain sistem dan pembuatan aplikasi.

5. Demonstrasi Berdasarkan rancangan solusi yang dibuat, demonstrasi dibangun dengan tujuan menguji aplikasi yang dibuat untuk melihat kesesuaian rancangan dengan harapan yang ingin dicapai.

6. Pengujian Setelah rancangan dan demonstrasi/simulasi didapatkan, pengujian terhadap aplikasi dilakukan dalam 2 (dua) tahapan. Tahapan pertama adalah dengan melakukan debugging terhadap aplikasi menggunakan metode blackbox. Tahapan kedua adalah dievaluasi terhadap kelompok pengguna (beta tester) sebagai bagian dari evaluasi dengan pengguna sekaligus menilai pencapaian tujuan dari aplikasi. Sampel digunakan untuk mengetahui pengguna yang melakukan evaluasi dengan ukuran berdasarkan populasi dan tingkat presisi [2]. Pertanyaan kuisioner mengandung pertanyaan mengenai tingkatan konsep (aspek utama yang dinilai), dimensi(sudut pandang yang akan dinilai), dan elemen (bagian-bagian detil dari dimensi) [3].

7. Analisis Analisis dilakukan terhadap hasil pengujian yang didapatkan. Analisis bertujuan memberikan gambaran kondisi aplikasi dan masukan mengenai arah pengembangan lebih lanjut.

8. Pelaporan Temuan Penelitian Laporan temuan penelitian berdasarkan data dan hasil analisis yang ada dibuat dan dilaporkan. Diharapkan hasil penelitian dapat $\backslash$ memberikan kontribusi dalam mengatasi permasalahan yang ada.

\section{DESAIN DAN IMPLEMENTASI SISTEM}

\section{Desain Sistem}

Desain sistem adalah sebuah proses menerjemahkan kebutuhan pemakai informasi ke dalam alternatif rancangan sistem informasi. Desain sistem dilakukan berdasarkan informasi yang didapatkan oleh analisis sistem. Menurut George M.Scott desain sistem menentukan bagaimana suatu sistem akan menyelesaikan apa yang mesti diselesaikan, tahap ini menyangkut mengkonfigurasi dari komponen- komponen perangkat lunak dan perangkat keras dari suatu sistem sehingga setelah instalasi dari sistem akan benar- benar memuaskan rancang bangun yang telah di tetapkan pada akhier tahap analisis sistem. 
Definisi desain sistem sebagai penggambaran, perencanaan, dan pembuatan sketsa atau pengaturan beberapa elemen yang terpisah ke dalam satu kesatuan yang utuh dan berfungsi. sebuah proses yang terdiri atas lima kegiatan.

a. Menentukan secara tepat dan terperinci kebutuhan dan bentuk-bentuk informasi yang sebenarnya diperlukan untuk menunjang.

b. Mengatur semua kebutuhan serta membaginya secara sistematis pada beberapa tahap dan bagian, yang nantinya akan dioperasikan secara standar untuk menghemat waktu dan biaya

c. Menentukan cara pelaksanaan tiap-tiap tugas tersebut.

d. Menentukan tingkat ukuran mutu untuk menilai keberhasilan dan Ketidak berhasilan dari tiap-tiap performa tugas-tugas tersebut.

e. Menghilangkan sebanyak mungkin pekerjaan yang akan menghambat implementasi sistem, seperti terjadinya duplikasi (pengulangan yang tidak perlu) mengenai fungsi, tujuan operasi, data, formulir-formulir data masukan, dan laporan-laporan yang sejenis. Disamping itu, juga mengurangi sebanyak mungkin hal-hal yang tidak bermanfaat, yang mungkin terdapat dalam sistem dan prosedur, aliran data yang tidak efisien, dan laporan-laporan yang kurang bermanfaat atau bahkan tidak berguna.

\section{UML (Unified Modeling Language)}

UML adalah UML merupakan singkatan dari "Unified Modelling Language" yaitu suatu metode permodelan secara visual untuk sarana perancangan sistem berorientasi objek, atau definisi UML yaitu sebagai suatu bahasa yang sudah menjadi standar pada visualisasi, perancangan dan juga pendokumentasian sistem software.

\section{Use Case Diagram}

Use case diagram yaitu salah satu jenis diagram pada UML yang menggambarkan interaksi antara sistem dan aktor, use case diagram juga dapat men-deskripsikan tipe interaksi antara si pemakai sistem dengan sistemnya. Diagram ini menunjukkan fungsionalitas suatu sistem atau kelas dan bagaimana sistem berinteraksi dengan dunia luar.Use-case diagram dapat digunakan selama proses analisa untuk menangkap requirements atau permintaan terhadap sistem dan untuk memahami bagaimana sistem tersebut harus bekerja. Adapun gambaran dari use case diagram dari Sensus Sms Gateway Berbasis Web Based Kelurahan Koto Luar Kecamatan Pauh Kota Padang sebagai berikut seperti yang tergambar seperti dibawah ini : 


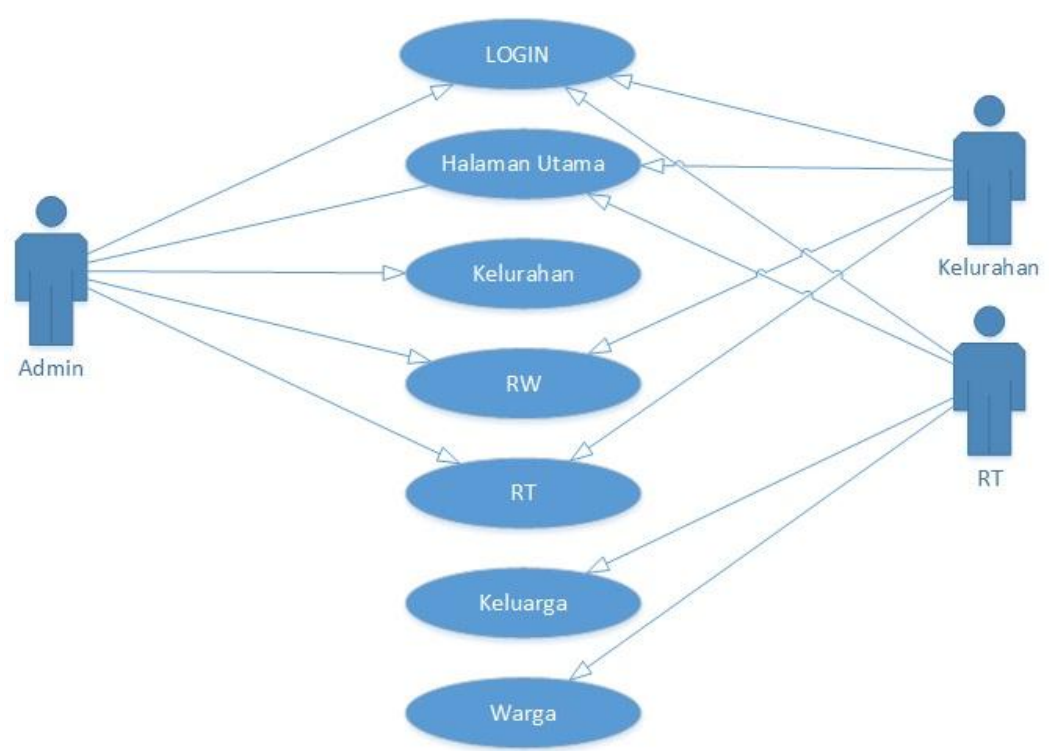

\section{Gambar 1 Use case Diagram}

Disini dapat dilihat bahwa ada tiga aktor yang terlibat didalam use case diagram yakni ada admin, kelurahan, dan rt dalam hal ini ketiga aktor tersebut memiliki peran masing-masing didalam kerjaannya sebagaimana yang dapat dilihat pada gambar 1 diatas.

\section{Activity Diagram}

Activity diagram atau diagram aktivitas yaitu salah satu jenis diagram pada UML yang dapat memodelkan proses-proses apa saja yang terjadi pada sistem. Menggambarkan rangkaian aliran dari aktivitas, digunakan untuk mendeskripsikan aktifitas yang dibentuk dalam suatu operasi sehingga dapat juga digunakan untuk aktifitas lainnya seperti use case atau interaksi hal ini dapat dilihat dari diagram aktivitas yang tampak seperti dibawah ini pada gambar 2, 3, dan 4 pada masing aktivitas terdapat jenis kegiatan pada tingkatan yang berbeda mulai dari admin, RT 


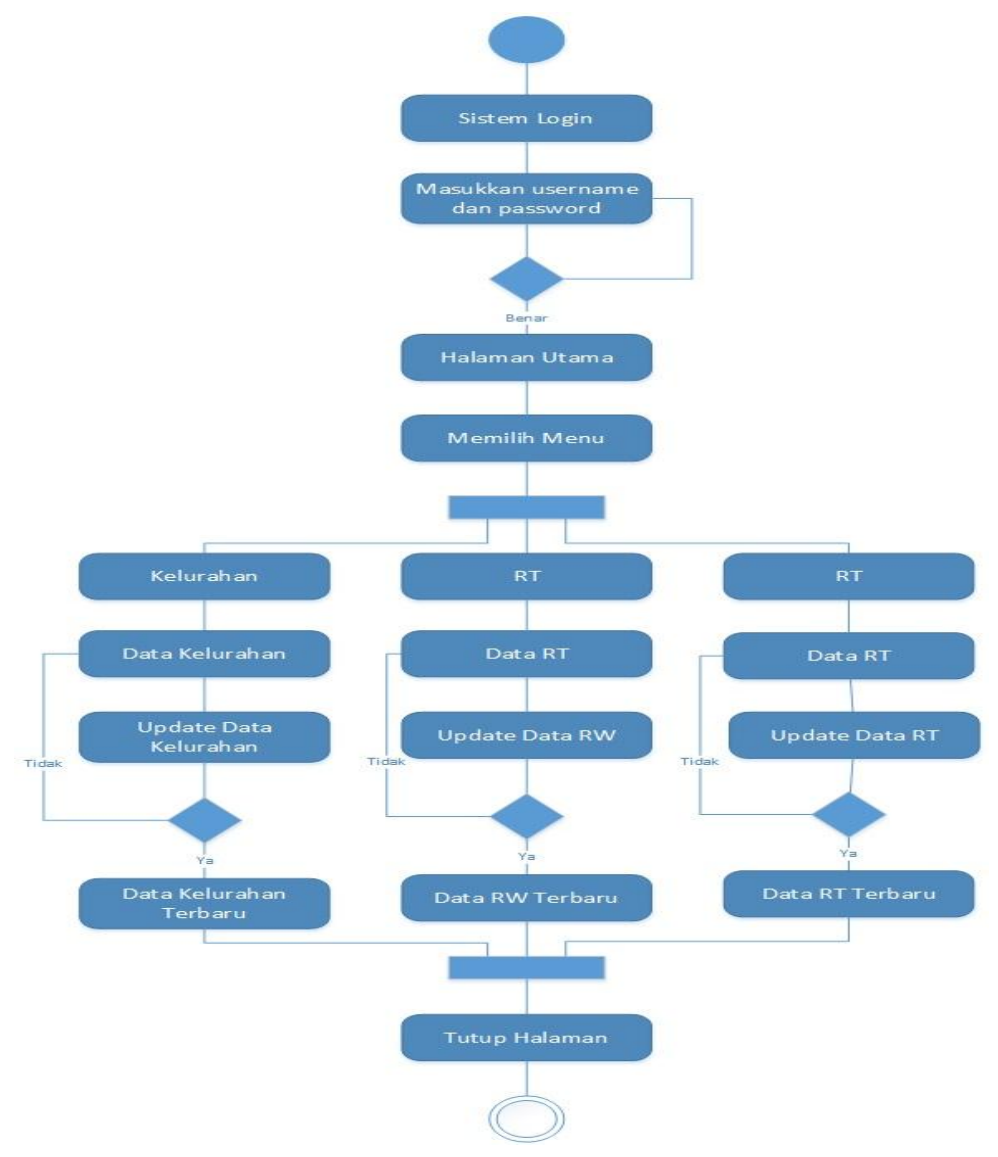

Gambar 2 activity diagram admin 


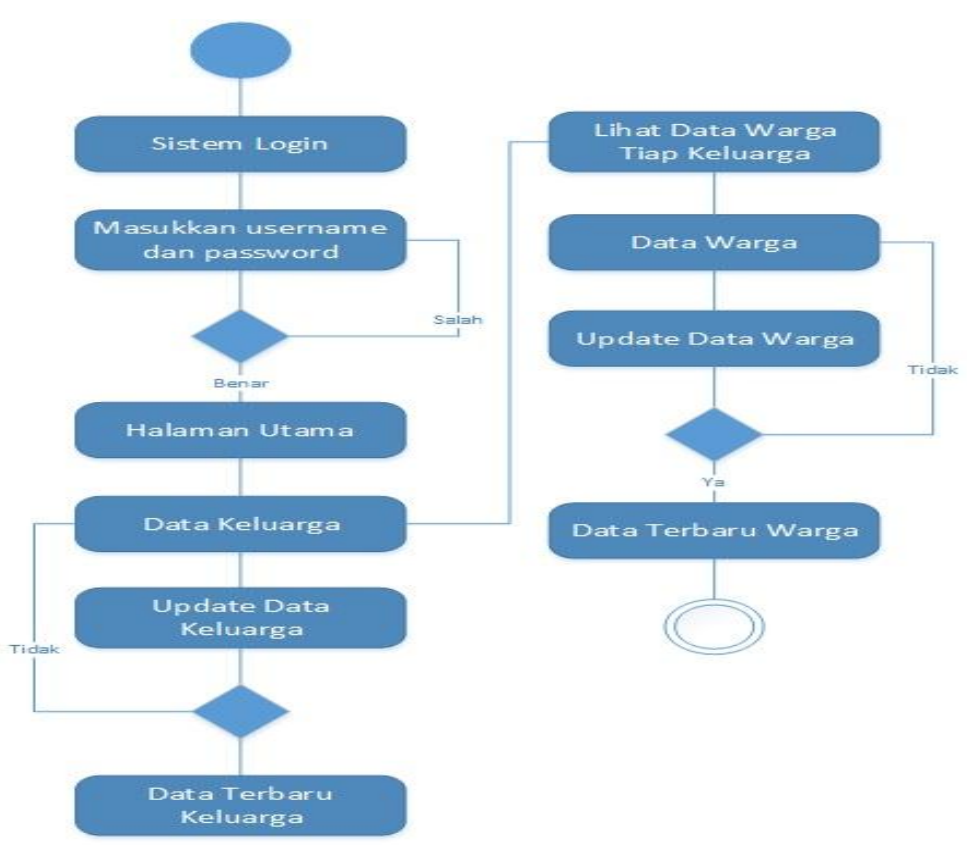

Gambar 3 activity diagram RT

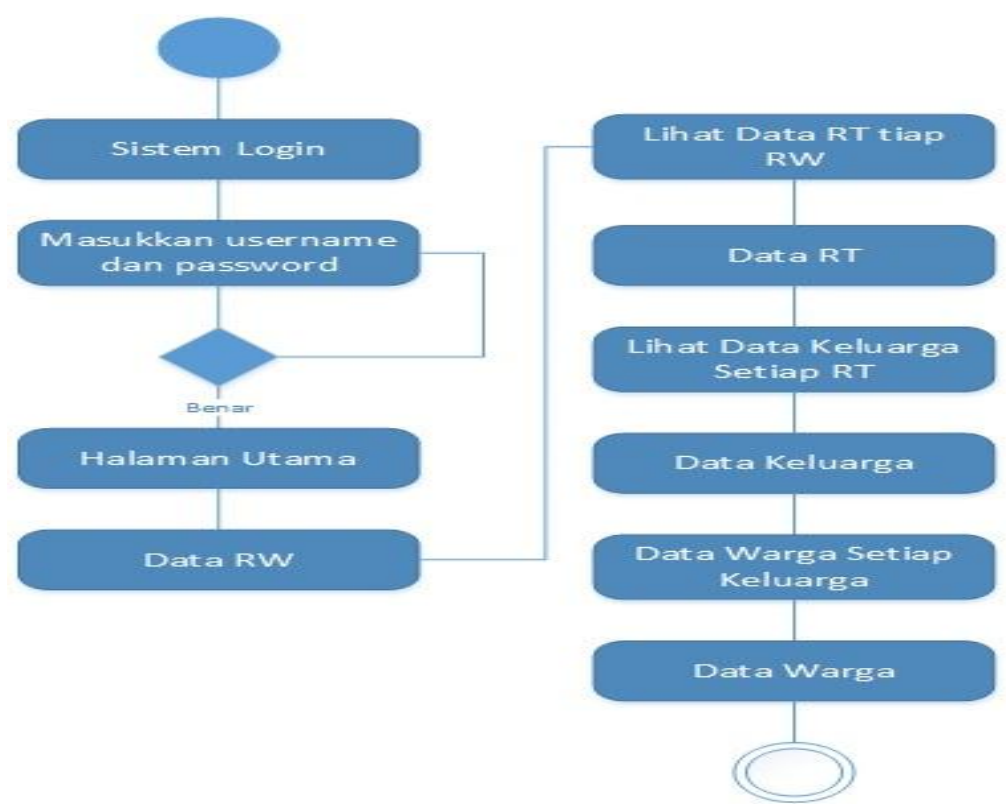

Gambar 4 activity diagram kelurahan 


\section{Sequence Diagram}

Sequence Diagram adalah suatu diagram yang menggambarkan interaksi antar obyek dan komunikasi antara obyek-obyek tersebut. Diagram ini juga menunjukkan serangkaian pesan yang dipertukarkan oleh obyek - obyek yang melakukan suatu tugas atau aksi tertentu kemudian diurutkan dari kiri ke kanan, aktor yang menginisiasi interaksi biasanya terletak pada bagian paling kiri dari diagram.Pada diagram ini, dimensi vertikal merepresentasikan waktu. Bagian paling atas dari diagram menjadi titik awal dan waktu berjalan ke bawah sampai dengan bagian dasar dari diagram. Garis Vertical, disebut lifeline, dilekatkan pada setiap obyek atau aktor. Kemudian, lifeline tersebut digambarkan menjadi kotak ketika obyek melakukan suatu operasi, kotak tersebut disebut activation box. Obyek dikatakan mempunyai live activation pada saat tersebut.Pesan yang dipertukarkan antar obyek digambarkan sebagai sebuah anak panah antara activation box pengirim dan penerima. Kemudian diatasnya diberikan label pesan. Hal ini dapat terlihat pada gambar 5, 6, dan 7 seperti yang terlihat dibawah ini.

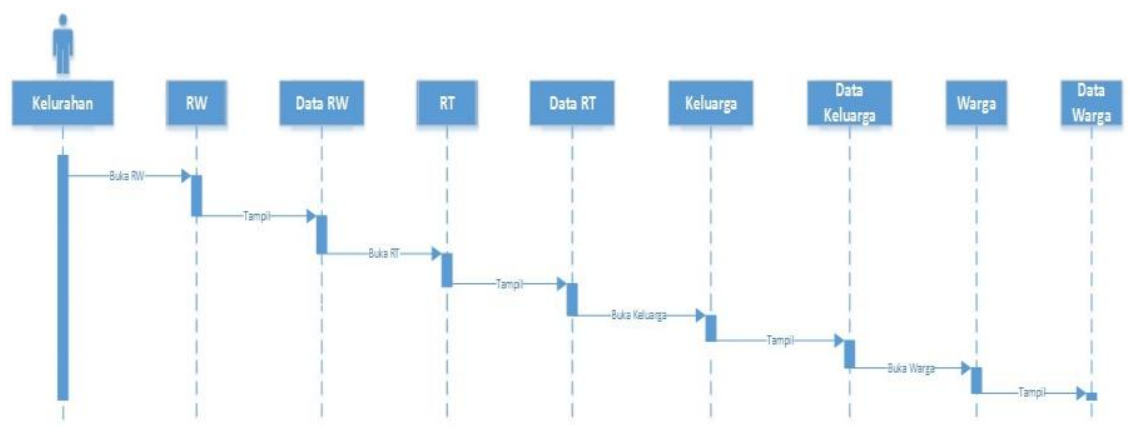

Gambar 5 sequence kelurahan 


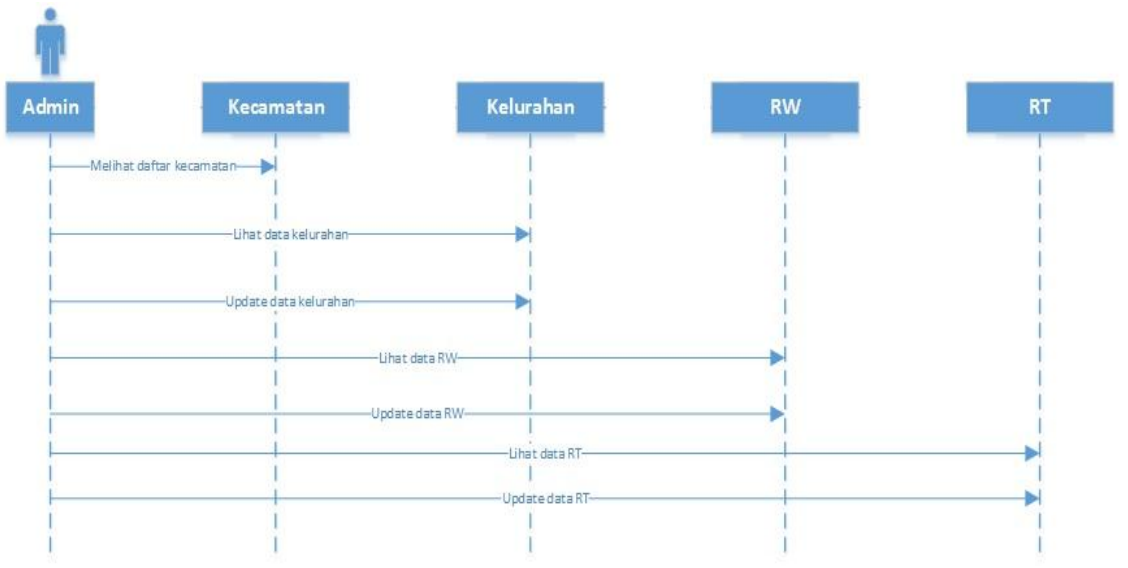

Gambar 6 sequence diagram admin

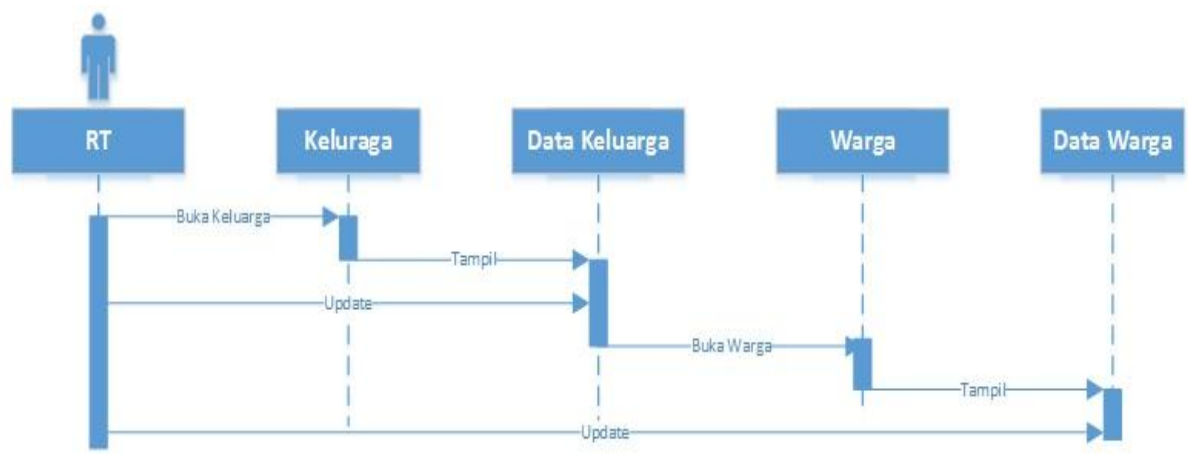

Gambar 7 sequence diagram RT 


\section{Class Diagram}

Class diagram adalah diagram yang menggambarkan struktur sistem dari segi pendefinisian kelas-kelas yang akan dibuat untuk membangun sistem. Kelas memiliki 3 bagian utama yaitu attribute, operation, dan name. kelas-kelas yang ada pada struktur sistem harus dapat melakukan fungsi-fungsi sesuai dengan kebutuhan sistem. Sususan struktur kelas yang baik pada diagram kelas sebaiknya memiliki jenis-jenis kelas berikut seperti yang terlihat pada gamabar class diagram dibawah ini :

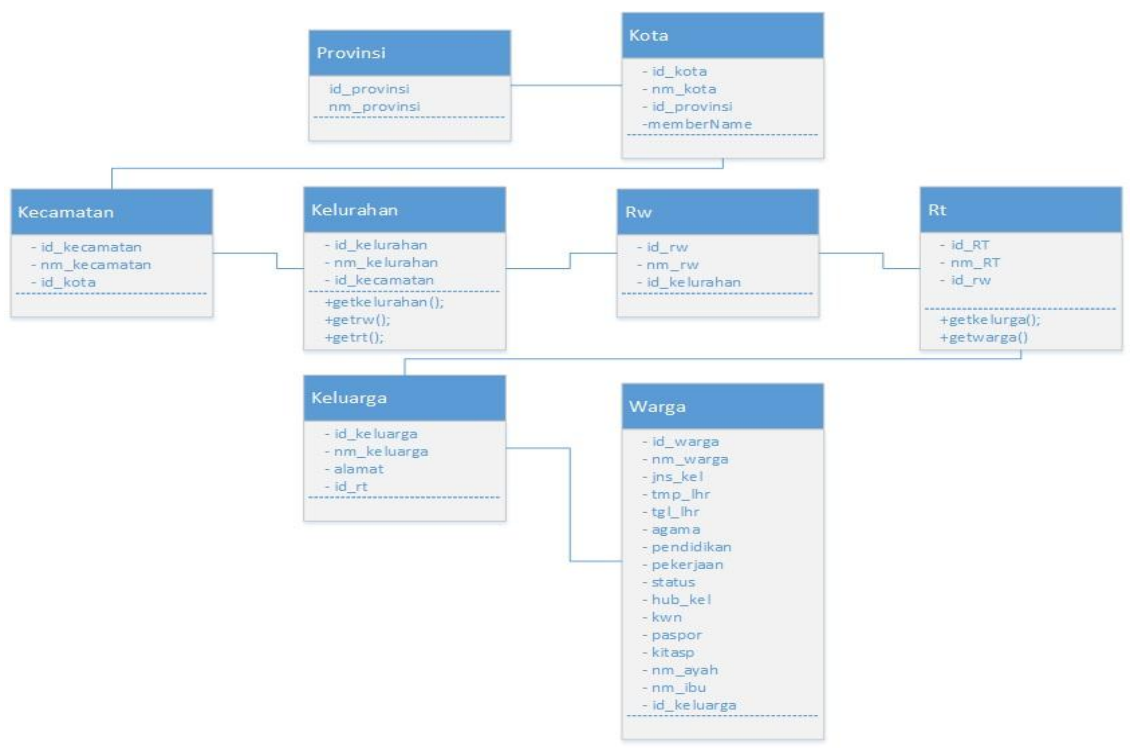

\section{Gambar 8 class diagram}

\section{Implementasi Sistem}

Implementasi sistem adalah tahap penerapan sistem yang akan dilakukan jika sistem disetujui termasuk program yang telah dibuat pada tahap perancangan sistem agar siap untuk dioperasikan. Implementasi Sistem merupakan tahap dimana sistem yang telah dirancang pada tahap sebelumnya diterapkan, berupa perangkat lunak maupun perangkat keras yang digunakan. Dengan penerapan sistem yang dirancang, hasilnya dapat dioperasikan dan digunakan secara optimal sesuai kebutuhan.merupakan kumpulan dari elemen-elemen yang telah didesain kedalam bentuk pemograman untuk menghasilkan suatu tujuan yang dibuat berdasarkan kebutuhan seperti yang terlihat pada gambar dibawah ini : 


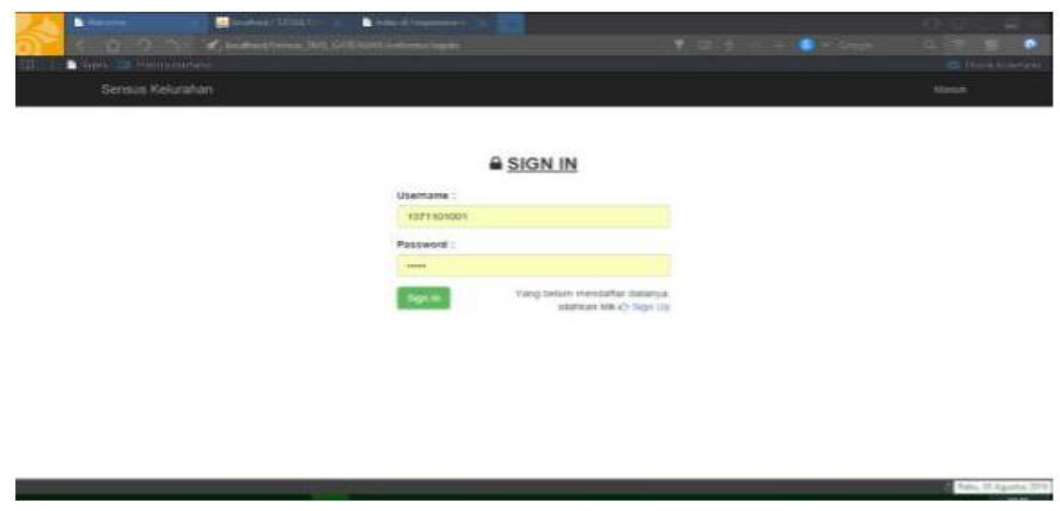

Gambar 9 Login Admin

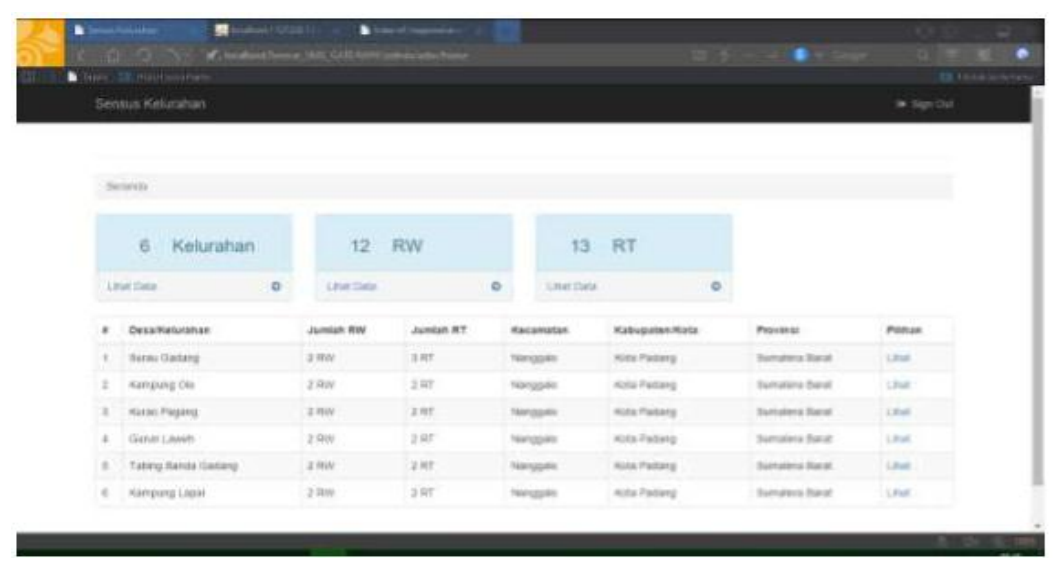

Gambar 10 Input Data

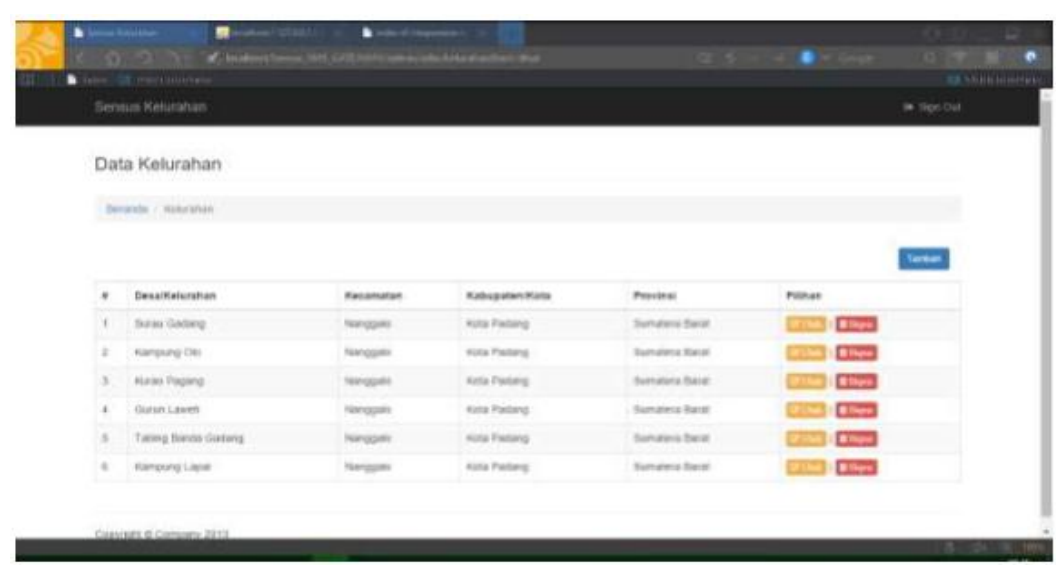

Gambar 11 Input Data kelurahan 


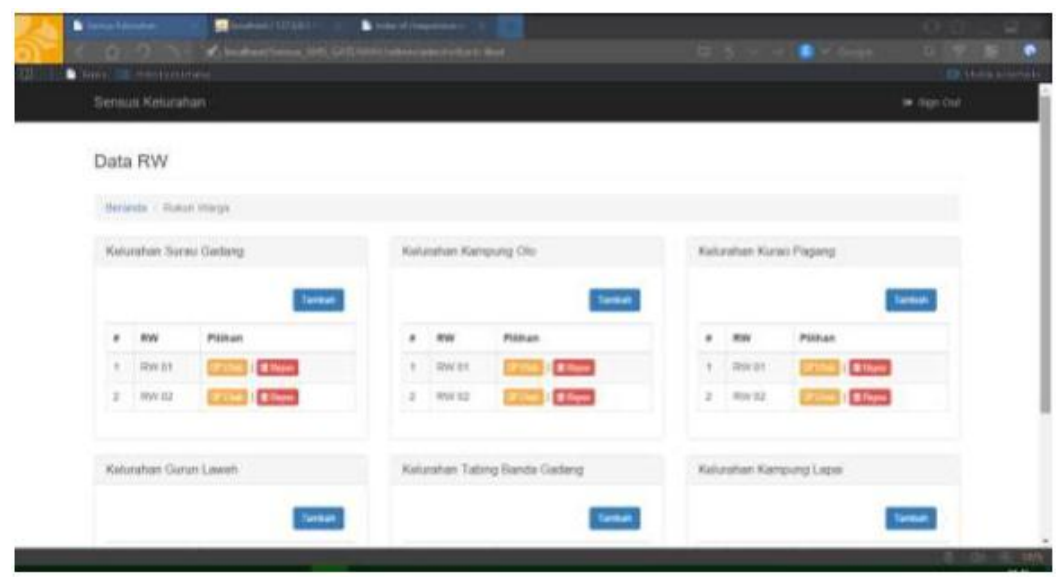

Gambar 12 Input Data RW

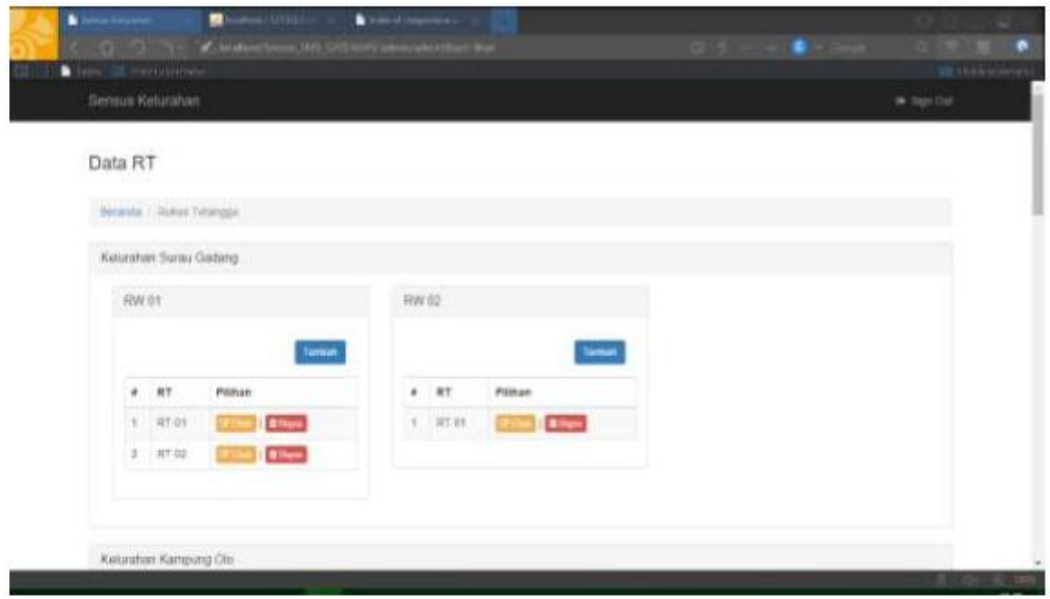

Gambar 13 Input Data RT

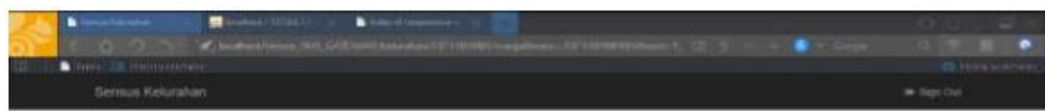

Dato Warga ane

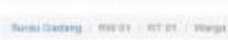

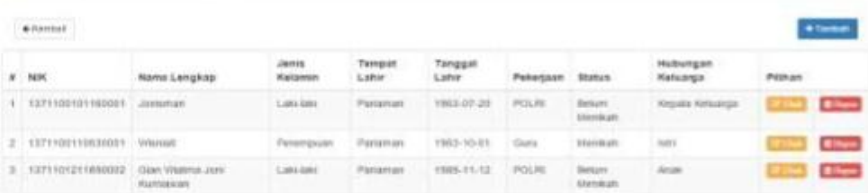

Gambar 14 Input Data Per Kepala Keluarga 


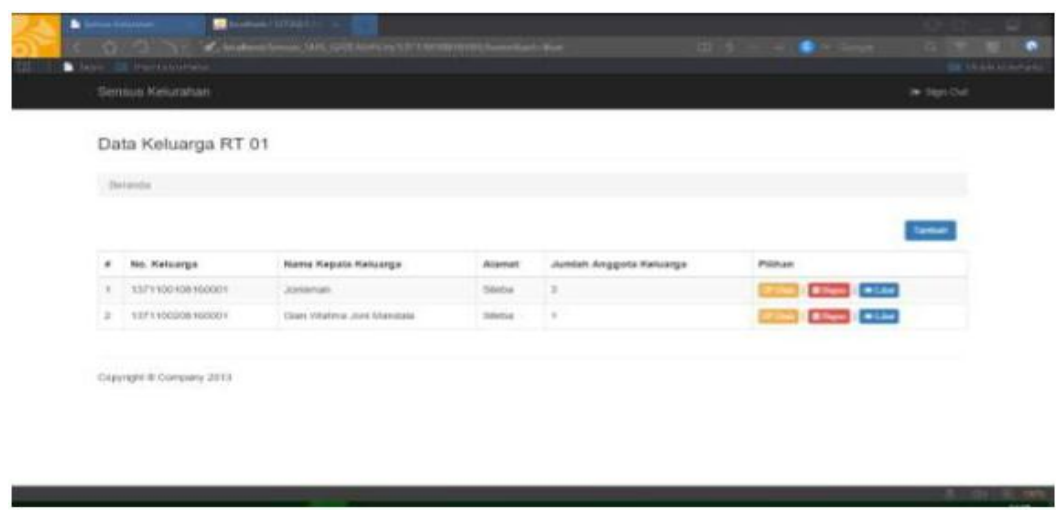

\section{Gambar 15 Input Data Warga Per RT}

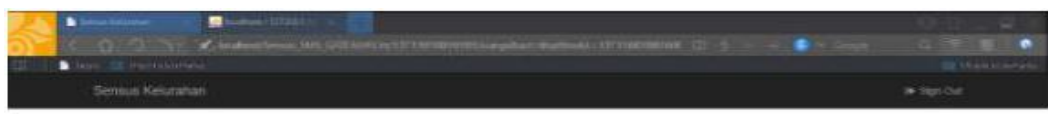

Data Keluarga No. 1371100108160001

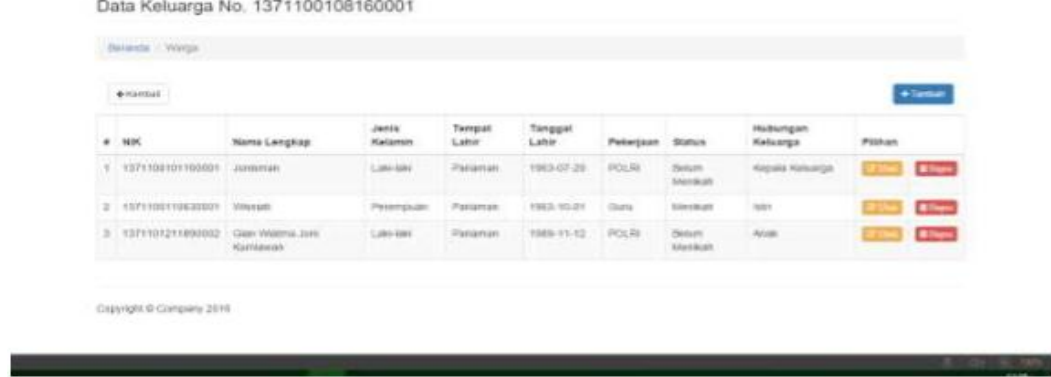

Gambar 16 Input Data Keluarga

\section{KESIMPULAN DAN SARAN}

\section{Kesimpulan}

Setelah menganalisa faktor-faktor-faktor internal dan ekternal perkembangan sistem ini maka aplikasi yang dibangun sangat membantu petugas sensus dilapangan. Sehingga mempermudah kinerja petugas serta mempercepat proses pengumpulan dan pengolahan data. Adapun manfaat dari penelitian ini dapat mempermudah kinerja petugas dan serta dapat mempersingkat waktu pengumpulan data serta pengolahan data.

\section{Saran}

Untuk mendukung aplikasi ini nantinya sistem harus di support dengan infrastruktur yang baik agar sistem bisa digunakan dengan maksimal. Dalam pengembangan kedepan nantiya akan disesuaikan dengan kebutuhan serta perkembangan teknologi seperti android. 


\section{REFERENSI}

Katankar, V. K. A. V. T. (2010). Short Message Service using SMS Gateway. International Journal, 2(4), 1487-1491.

D, N. P. S., \& Sriyanto, S. (2013). Perancangan Sistem Informasi Pemesanan Berbasis Sms Gateway Untuk Memperbaiki Informasi Persediaan (Studi Kasus : Pt. Indotirta Jaya Abadi

Saleem, M., \& Doh, K. G. (2009). Generic information system using SMS gateway. In ICCIT 2009 - 4th International Conference on Computer Sciences and Convergence Information Technology (pp. 861-866). http://doi.org/10.1109/ICCIT.2009.99

Thoyib. (2010). Pelayanan pelanggan berbasis SMS gateway. Jurnal UMB/Aplikasi SMS Gateway, 1-8. Retrieved from http://mercubuana.ac.id

Widhiarso, Y., \& Kusuma Riasti, B. (2013). Rancang bangun sistem informasi nilai akademik dan presensi siswa berbasis sms gateway pada SDN 3 Tulakan. Rancang Bangun Sistem Informasi Nilai Akademik Dan Presensi Siswa Berbasis Sms Gateway Pada SDN Tulakan 3, 2(4), 1-6.

Siang, B. K., Bin Ramli, A. R., Prakash, V., \& Bin Syed Mohamed, S. A. R. (2003). SMS gateway interface remote monitoring and controlling via GSM SMS. In 4th National Conference on Telecommunication Technology, NCTT 2003 Proceedings (pp. 84-87). http://doi.org/10.1109/NCTT.2003.1188308

Lu, X., Lei, W., \& Zhang, W. (2012). The design and implementation of XMPP-based SMS gateway. In Proceedings - 2012 4th International Conference on Computational Intelligence, Communication Systems and Networks, CICSyN 2012 (pp. 145-148). http://doi.org/10.1109/CICSyN.2012.35

Wiharto, Y. (2011). Sistem Informasi Akademik Berbasis SMS Gateway. Jurnal Teknologi Dan Informatika (TEKNOMATIKA), 1(1), 1-28. Retrieved from http://news.palcomtech.com/wpcontent/uploads/2012/01/YUDIWIHARTOTE01012011.pdf

Goel, U., Shah, K., \& Qadeer, M. A. (2011). The personal SMS gateway. In 2011 IEEE $3^{\text {rd }}$ International Conference on Communication Software and Networks, ICCSN 2011 (pp. 617-621). http://doi.org/10.1109/ICCSN.2011.6014345

Persada, S. F., Razif, M., Lin, S. C., \& Nadlifatin, R. (2014). Toward Paperless Public Announcement on Environmental Impact Assessment (EIA) through SMS Gateway in Indonesia.Procedia Environmental Sciences, 20, 271-279. http://doi.org/10.1016/j.proenv.2014.03.034

Kapsalis, V., Koubias, S., \& Papadopoulos, G. (2002). OPC-SMS: A wireless gateway to OPCbased data sources. Computer Standards and Interfaces, 24(5), 437-451. http://doi.org/10.1016/S0920-5489(02)00067-3

Prieto, A. G., Cosenza, R., \& Stadier, R. (2004). Policy-based congestion management for an SMS gateway. In Proceedings - Fifth IEEE International Workshop on Policies for Distributed Systems and Networks, POLICY 2004 (pp. 215-218). http://doi.org/10.1109/POLICY.2004.1309172

Aradea, \& Dewanto, R. A. (2007). Aplikasi SMS Gateway Dengan Koreksi Kesalahan Menggunakan Fuzzy String Matching. Seminar Nasional Aplikasi Teknologi Informasi 2007 (SNATI 2007), 2007(Snati), 1-7. 